\title{
Numerical approach for comparative performance study of tube type and box type hybrid photovoltaic/thermal system
}

\author{
Bhattarai, Sujala* Kim, Dae-Hyun**
}

*Graduate School, Dept. of Biosystems Engineering, Kangwon National University,

**Dept. of Biosystems Engineering, Kangwon National University(daekim@kangwon.ac.kr)

\section{시뮬레이션을 통한 박스형과 튜브형 태양광열 복합 시스템의 성능 분석}

\author{
바타라이 수절라*, 김대현**
}

*강원 대학교 바이오시스템공학과 대학원, **강원대학교 바이오시스템공학과(daekim@kangwon.ac.kr)

\begin{abstract}
태양광열 복합 시스템(photovoltaic/thermal hybrid solar system, PV/T)은 태양광 모듈 및 태양열 집열판의 단일화를 통한 전기 및 열에너지의 동시 생산이 가능하도록 구성되고 기존 태양광 모듈의 온도 상승에 따른 효율 저하의 문제점을 보완 및 발생하는 열을 회수하여 온수 생산이 가능한 장치이다. 본 연구에서는 액체형 $\mathrm{PV} / \mathrm{T}$ 시스템의 대표적인 두 형태인 박스형과 튜브형의 성능 검증을 위하여 수학적 모델링을 통한 두 시스템의 열 및 전기적 성능을 비교 - 분석하였다. 모델링 은 에너지 평형식을 이용하여 시간에 따른 각 부분의 온도의 변화를 예측할 수 있도록 수립되었으며 계산된 결과를 기준 으로 전기, 열, 및 전체효율을 도출해 내고, 이를 바탕으로 두 시스템의 성능을 분석하였다. 시뮬레이션 결과를 바탕으로, 박스형 $\mathrm{PV} / \mathrm{T}$ 시스템의 최고 온수 온도는 $52^{\circ} \mathrm{C}$ 로 예측되었고, 반면에 튜브형은 $48^{\circ} \mathrm{C}$ 에 머물렀다. 또한 열효율은 박스형이 최대 $51 \%$, 튜브형이 $41 \%$, 전기효율은 박스형이 약 $14 \%$, 그리고 튜브형이 $13 \%$ 로 나타났으며, 전체효율은 박스형이 $73 \%$, 그리고 튜브형이 $64 \%$ 로 나타나 박스형 $\mathrm{PV} / \mathrm{T}$ 시스템이 튜브형보다 더 나은 성능을 가지는 것으로 예측되었다. 이는 박스 형이 튜브형보다 태양광 모듈과 온수와의 접촉면적이 넓어 더 많은 열전달이 발생하기 때문으로 사료된다.
\end{abstract}

Keywords : 태양광열(Photovoltaic/thermal), 시뮬레이션(Simulation), 효율(Efficiency), 성능분석(Performance analysis)

\section{Nomenclature}

A : aperture area, $\mathrm{m}^{2}$

C : specific heat capacity, $\mathrm{J} \mathrm{kg}^{-1} \mathrm{~K}^{-1}$

$\mathrm{h} \quad$ : heat transfer coefficient, $\mathrm{W} \mathrm{m} \mathrm{m}^{-2} \mathrm{~K}^{-1}$

$\mathrm{E}$ : electrical power output, $\mathrm{W} \mathrm{m}^{-2}$

M : mass, kg

$\dot{m} \quad$ : mass flow rate, $\mathrm{kg} \mathrm{s}^{-1}$

$\mathrm{P}$ : packing factor

$\mathrm{Ra} \quad$ : Rayleigh number

$\mathrm{G}$ : solar radiation, $\mathrm{W} \mathrm{\textrm {m } ^ { - 2 }}$

$\mathrm{T}$ : temperature, ${ }^{\circ} \mathrm{C}$

$\mathrm{t} \quad$ : time, $\mathrm{s}$

투고일자 : 2011년 6월 30일, 심사일자 : 2011년 7월 5일, 게재확정일자 : 2011년 9월 15일

교신저자 : 김대현(daekim@kangwon.ac.kr) 


\section{Greek}

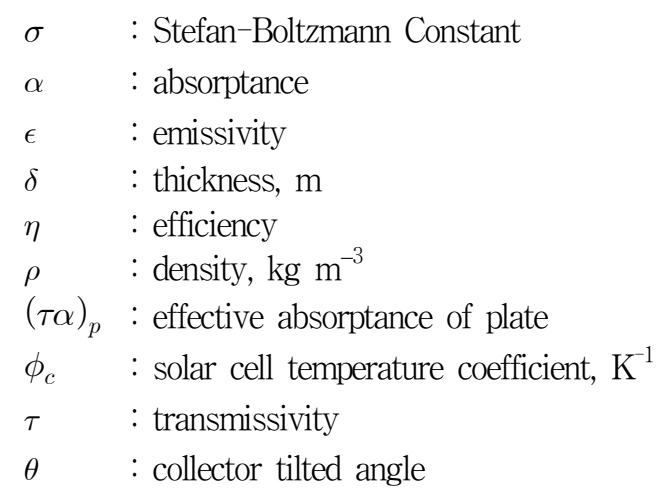

\section{Superscript}

$+\quad$ : critical

$\begin{array}{ll} & \text { Subscripts } \\ \text { a } & \text { : ambient air } \\ \text { c } & \text { : collector } \\ \text { cd } & \text { : conductive } \\ \text { cv } & \text { : convective } \\ \text { e } & \text { : electrical } \\ \text { g } & \text { : glazing } \\ \text { i } & \text { : inner; inlet; insulation material } \\ \text { o } & \text { : outlet } \\ \text { p } & \text { : PV plate } \\ \text { r } & \text { : radiative } \\ \text { t } & \text { : tube; tube bonding } \\ \text { th } & \text { : thermal } \\ \text { tk } & \text { : tank } \\ \text { w } & \text { : water } \\ \text { wind } & \text { : wind induced } \\ 1 & \text { : channel or tube inlet } \\ 2 & \text { : channel or tube outlet }\end{array}$

\section{Introduction}

A photovoltaic/thermal (PV/T) solar system is the solar technology that allows for simultaneous conversion of solar energy into both electricity and heat. Photovoltaic(PV) cell cannot absorb the solar energy within the full radiation spectrum range. Most part of the incident energy (around 85\%) is rejected to the surrounding environment in the form of heat and this heat has negative effects in the electrical output of crystalline Si based PV cell. The electrical conversion efficiency reduces 0.4 to $0.5 \%$ per degree rise in temperature for crystalline-silicon cells ${ }^{1223)}$ which causes significant drop of electric energy. PV/T system overcomes this disadvantage and improves both the electrical and thermal performance of the system. This also increases the aesthetic views, reduces the space and material cost as compared to the separated PV and solar thermal systems being placed side by side ${ }^{4)}$. The PV/T system has been analysed both for steady state and dynamic conditions. The steady state analysis was done through the quasi-steady-state analysis using hourly weather data. With the use of steady state models, performance of $\mathrm{PV} / \mathrm{T}$ collector had been studied both experimentally ${ }^{5 / 6) 7}$ and numerically ${ }^{89910)}$. Zondag et al. ${ }^{11)}$ introduced extensive 3D dynamic model which was not developed for the simulation purpose. Later on, Chow ${ }^{12)}$ developed the dynamic model for the single glazed flat plate water-heating $\mathrm{PV} / \mathrm{T}$ collector and verified through experiments.

Water type $\mathrm{PV} / \mathrm{T}$ systems have been distinguished on the basis of water flow pattern. The commonly used water type $\mathrm{PV} / \mathrm{T}$ systems are sheet and tube type, channel, free flow, and two absorber type ${ }^{13)}$. Zondag et al. ${ }^{14)}$ studied the various concepts of the PV/T systems and found that channel below transparent $\mathrm{PV}$ design gave the best efficiency. The problems reported in the sheet and tube type collectors were fin efficiency and bonding quality ${ }^{12)}$. The PV encapsulation 
using the TPT (tedlar-polyester-tedlar) and the EVA (ethylene-vinyl acetate) layers caused the good bonding between the PV and thermal absorber. The temperature difference between the front part and the back sides of the absorber was found not more than $1^{\circ} \mathrm{C}^{15)}$. Chow et al. ${ }^{16)}$ recommended the flat-box thermal absorber $\mathrm{PV} / \mathrm{T}$ system for the improvement of fin efficiency. The results showed that the flat box structure improved heat transfer and durability of the $\mathrm{PV} / \mathrm{T}$ system.

The aim of this work is to numerically study the thermal and electrical performances of a box type and tube type $\mathrm{PV} / \mathrm{T}$ systems. The comparative performance analysis of tube type and box type PV/T system was investigated on the basis of total electrical and thermal output produced per unit area of collector with respect to same packing factor, mass flow rate and weather conditions.

\section{Mathematical model}

The dynamic model developed by the Chow ${ }^{12)}$ and Chow $^{16)}$ were used for the simulation study of tube type and box type $\mathrm{PV} / \mathrm{T}$ system respectively. The model was developed for the aperture area of $1 \mathrm{~m}$ width and $1 \mathrm{~m}$ length. The packing factor was 0.9375 , which was the ratio of solar module area to the absorber area. The polycrystalline solar cell of cell conversion efficiency $14.5 \%$ was used for the simulation. The solar module having open circuit voltage $37.1 \mathrm{~V}$, maximum power voltage $31 \mathrm{~V}$, short circuit current $8.05 \mathrm{~A}$ and maximum power $240 \mathrm{~W}$ at standard test conditions was selected. The mass flow rate of each system was
$76 \mathrm{~kg} / \mathrm{hr}$. The flow in the box type was designed for the natural flow system and for the tube type, it is considered as a forced flow system.

\subsection{System description}

The PV/T system generally consists of glazing, photovoltaic panel, thermal absorber plate and insulations. Solar cell is inserted in the encapsulated materials. Flat box type aluminum alloy collector consists of small channels through which water is passed. The PV module is cleaved to the upper portion of the aluminum alloy thermal absorber. All the above components are also similar to the sheet and tube type $\mathrm{PV} / \mathrm{T}$ system except bonding the water tubes with absorber plate. There is metallic bond between the absorber plate and the water tubes and the insulation air layer between the front gazing and the PV encapsulation. The basic difference between the tube type and box type systems are shown in Table 1. Due to the greater numbers of water channels, covering the total surface area of the thermal absorber, on the box type collectors, its fin efficiency was expected to be higher than that of tube type system. The tube type system consisted of fewer numbers of tubes in contact with the absorber as shown in Fig. 2 (b) and (c). The edges and bottom of both types of the panel are inserted with thermal insulation. The entire components are housed in a steel frame. The schematic diagram of the components of flat box type and sheet and tube type are shown in Fig. 1 and Fig. 2 (a) and (b) respectively. 


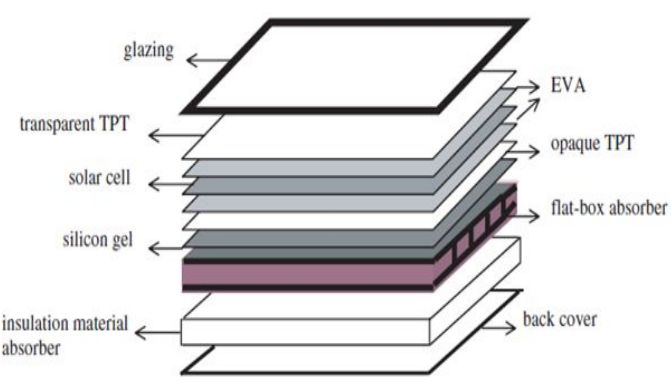

Fig. 1 Constituents layer of box type PV/T system ${ }^{16)}$

a)
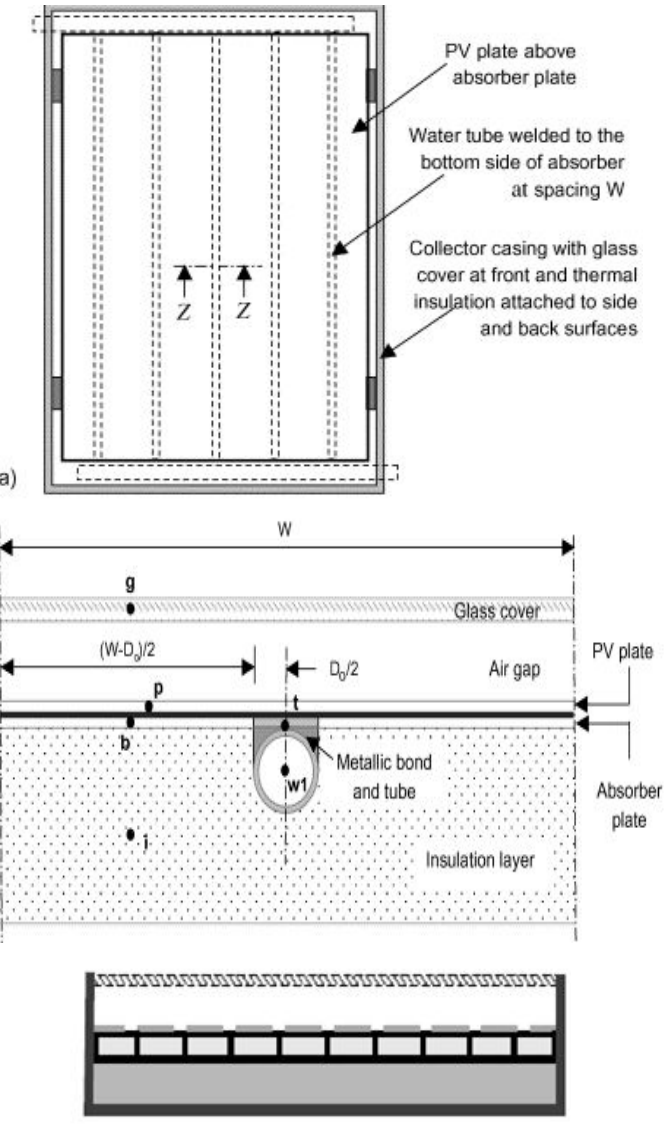

c)

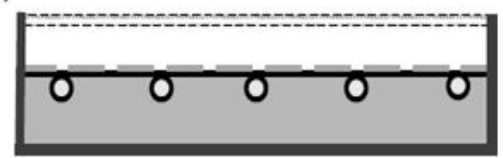

d)

Fig. 2 Sheet and tube type PV/T collector (a) front view (b) section $Z-Z^{12)}$ (c) side view of box type (d) side view of tube type $\mathrm{PV} / \mathrm{T}$ system.

\subsection{The system model}

To describe a model for both systems, a mathematical simulation using energy balance should be addressed. The full details of energetic models are given in $\mathrm{Chow}^{12)}$ for the tube type and $\mathrm{Chow}^{16)}$ for the box type.

Table 1. Major differences in design between the box and tube type PVT system

\begin{tabular}{|l|l|l|}
\hline Descriptions & Tube Type & Box type \\
\hline Tube spacing & Required & $\begin{array}{l}\text { Not } \\
\text { required }\end{array}$ \\
\hline No of channels & 5 & 50 \\
\hline Bonding & $\begin{array}{l}\text { Bonding between } \\
\text { absorber plate } \\
\text { and tube }\end{array}$ & No bonding \\
\hline $\begin{array}{l}\text { Contacting } \\
\text { area between } \\
\text { the absorber } \\
\text { plate and water } \\
\text { channels }\end{array}$ & Partial & Full \\
\hline
\end{tabular}

\subsubsection{Box type PV/T system}

\section{Glazing}

$$
\begin{aligned}
\rho_{g} \delta_{g} C_{g} \frac{d T_{g}}{d t}= & G \alpha_{g}+\left(h_{w i n d}+h_{r, g a}\right)\left(T_{a}-T_{g}\right) \\
& +\left(h_{c v, c g}+h_{r, c g}\right)\left(T_{c}-T_{g}\right)
\end{aligned}
$$

$\underline{\text { Collector plate }}$

$$
\begin{gathered}
\rho_{c} \delta_{c} C_{c} \frac{d T_{c}}{d t}=G(\tau \alpha)_{p}-E+\left(h_{c v, c g}+h_{r, c g}\right)\left(T_{g}-T_{c}\right) \\
+h_{c v, c w} A_{w}\left(T_{w}-T_{c}\right)+\frac{T_{a}-T_{c}}{R_{i n}} \\
E=G \tau_{g} P \eta_{e}\left[1-\phi_{c}\left(T_{c}-25\right)\right]
\end{gathered}
$$

Water in the channel

$\rho_{w} A_{z} C_{w} \frac{d T_{w}}{d t}=h_{c v, c w} A_{w}\left(T_{c}-T_{w}\right)-\dot{m}_{w} C_{w}\left(T_{w 1}-T_{w 2}\right)$

$$
T_{w}-0.5 T_{w 2}-0.5 T_{w 1}=0
$$


Where, $A_{z}$ is the total cross sectional flow area and $A_{w}$ is the total surface area per unit area of collector. $T_{w}$ is the mean temperature of inlet $\left(T_{w 1}\right)$ and outlet temperature $\left(T_{w 2}\right)$ in the channel.

Water in the storage tank

$M_{t k} C_{t k} \frac{d T_{t k}}{d t}=m_{w} C_{w}\left(T_{t k, i}-T_{t k, 0}\right)+h_{t k} A_{t k}\left(T_{a}-T_{t k}\right)$

\section{Heat transfer coefficients}

The convective heat transfer between the cover glass and the ambient with wind speed $\left(u_{\text {wind }}\right)$ is given by

$$
h_{\text {wind }}=2.8+3.0 u_{\text {wind }}
$$

The radiative heat transfer coefficient between the front cover and the ambient environment is

$$
h_{r, g a}=\epsilon_{g} \sigma\left(T_{g}^{2}+T_{a}^{2}\right)\left(T_{g}+T_{a}\right)
$$

The radiative heat transfer coefficient between the front cover and the collector plate is

$$
h_{r, c g}=\frac{\sigma\left(T_{g}^{2}+T_{a}^{2}\right)\left(T_{g}+T_{a}\right)}{\frac{1}{\epsilon_{g}}+\frac{1}{\epsilon_{c}}-1}
$$

The following correlation equation ${ }^{18)}$ for the Nusselt number can be applied provided that $0 \leq R a \leq 10^{5}$ and $0^{\circ}<\theta<\theta^{+}$.

$$
\begin{aligned}
& N u=1+\left[\left(\frac{R a \cos \theta}{5730}\right)^{1 / 3}-1\right]^{*} \\
& +1.44\left[1-\frac{1708}{R a \cos \theta}\right]^{*}\left[1-\frac{1708[\sin (1.8 \theta)]^{1.6}}{R a \cos \theta}\right]
\end{aligned}
$$

Where []$^{*}$ in the equation is defined by $[\mathrm{X}]^{*}=(|\mathrm{X}|+\mathrm{X}) / 2 . \quad \theta^{+}$is the critical angle of the collector slope and can be taken as $60^{\circ}$ for a maximum error in $\mathrm{Nu}$ about $5 \%$, or as $75^{\circ}$ for error up to $10 \%$. For a water flow in a rectangular channel at an aspect ratio of 0.5 with uniform heat flux, the flow induced by the thermosyphon effect can be considered as fully developed and laminar in nature ${ }^{19)}$ in that $\mathrm{Nu}=4.11$.

\subsubsection{Tube type PV/T system}

\section{Glass}

$$
\begin{aligned}
M_{g} C_{g} \frac{d T_{g}}{d t}= & A_{g} G \alpha_{g}+A_{g}\left(h_{w i n d}+h_{r, g a}\right)\left(T_{a}-T_{g}\right) \\
& +A_{g}\left(h_{c v, c g}+h_{r, c g}\right)\left(T_{p}-T_{g}\right)
\end{aligned}
$$

\section{PV module}

$$
\begin{aligned}
M_{p} C_{p} \frac{d T_{p}}{d t}= & A_{p} G(\tau \alpha)_{p}-A_{p} E+A_{g p}\left(h_{c v, c g}+h_{r, c g}\right)\left(T_{g}-T_{p}\right) \\
& +h_{c l, c p} A_{c p}\left(T_{c}-T_{p}\right)+h_{c l, p t} A_{p t}\left(T_{t}-T_{p}\right)
\end{aligned}
$$

\section{$\underline{\text { Collector plate }}$}

$$
\begin{aligned}
M_{c} C_{c} \frac{d T_{c}}{d t}= & h_{c d, c p} A_{c p}\left(T_{p}-T_{c}\right)+h_{c d, c t} A_{c t}\left(T_{t}-T_{c}\right) \\
& +h_{c d, c i} A_{c i}\left(T_{i}-T_{c}\right)
\end{aligned}
$$

Tube Bonding

$$
\begin{aligned}
M_{t} C_{t} \frac{d T_{t}}{d t}= & h_{c d, c t} A_{c t}\left(T_{c}-T_{t}\right)+h_{c d, t i} A_{t i}\left(T_{i}-T_{t}\right) \\
& +h_{c, t w} A_{t w}\left(T_{w}-T_{t}\right)+h_{c d, p t} A_{p t}\left(T_{p}-T_{t}\right)
\end{aligned}
$$


$\underline{\text { Insulation }}$

$$
\begin{aligned}
M_{i} C_{i} \frac{d T_{i}}{d t}= & h_{c l, c i} A_{c i}\left(T_{c}-T_{i}\right)+h_{c l, t i} A_{t i}\left(T_{t}-T_{i}\right) \\
& +h_{c r, a i} A_{a i}\left(T_{a}-T_{i}\right)
\end{aligned}
$$

Water in the tube

$$
M_{w} C_{w} \frac{d T_{w}}{d t}=h_{c, t w} A_{t w}\left(T_{t}-T_{w}\right)+\dot{m}_{w} C_{w}\left(T_{w 1}-T_{w 2}\right)
$$

\section{Storage tank}

$$
M_{t k} C_{t k} \frac{d T_{t k}}{d t}=\dot{m}_{w} C_{w}\left(T_{t k, i}-T_{t k, 0}\right)+h_{t k} A_{t k}\left(T_{a}-T_{t k}\right)
$$

\section{Efficiency}

Electrical efficiency:

$$
\begin{aligned}
& \eta_{e}=P \eta_{\text {cell }} \\
& \eta_{\text {cell }}=\eta_{\text {ref }}\left[1-\phi_{c}\left(T_{p}-25\right)\right.
\end{aligned}
$$

Electrical efficiency depends upon the packing factor $(\mathrm{P})$, solar cell efficiency $\left(\eta_{\text {cell }}\right)$ and electrical conversion efficiency $\left(\eta_{\text {ref }}\right)$ at reference temperature $25^{\circ} \mathrm{C}$ and temperature coefficient $\phi_{c}$ of the solar cell.

\section{Thermal efficiency:}

$$
\eta_{t h}=\frac{\dot{m} C_{p}\left(T_{w 2}-T_{w 1}\right)}{A_{c}^{*} G(t)}
$$

Thermal efficiency depends upon the

\begin{tabular}{|c|c|}
\hline \multirow[t]{7}{*}{ Glazing } & Thickness $=0.004 \mathrm{~m}$ \\
\hline & Density $=2,525 \mathrm{~kg} \mathrm{~m}^{-3}$ \\
\hline & Specific heat capacity $=810 \mathrm{~J} \mathrm{~kg}^{-1} \mathrm{~K}^{-1}$ \\
\hline & normal transmissivity $=0.83$ \\
\hline & emissivity $=0.88$ \\
\hline & extinction coefficient $=26 \mathrm{~m}^{-1}$ \\
\hline & Total effective area $=1 \mathrm{~m}^{2}$ \\
\hline \multirow[t]{4}{*}{ PV module } & Packing factor $=0.9375$ \\
\hline & Solar cell temperature coefficient $=0.005 \mathrm{~K}^{-1}$ \\
\hline & Absorbptivity $=0.8$ \\
\hline & Emissivity $=0.8$ \\
\hline \multirow{4}{*}{$\begin{array}{l}\text { Thermal } \\
\text { collector }\end{array}$} & Material $=$ Aluminium \\
\hline & Specific heat capacity $=903 \mathrm{~J} \mathrm{~kg}^{-1} \mathrm{~K}^{-1}$ \\
\hline & Thickness $=0.002 \mathrm{~m}$ \\
\hline & Density $=2702 \mathrm{~kg} \mathrm{~m}^{-3}$ \\
\hline \multirow[t]{6}{*}{ Tube bonding } & Mass density $=8960 \mathrm{~kg} \mathrm{~m}^{-3}$ \\
\hline & Thickness $=0.002 \mathrm{~m}$ \\
\hline & Specific heat $=385 \mathrm{~J} \mathrm{~kg}^{-1} \mathrm{~K}^{-1}$ \\
\hline & Density $=2702 \mathrm{~kg} \mathrm{~m}^{-3}$ \\
\hline & Thermal conductivity $=210 \mathrm{Wm}^{-1} \mathrm{~K}^{-1}$ \\
\hline & Bond width $=0.01 \mathrm{~m}$ \\
\hline \multirow[t]{3}{*}{ Insulation } & Thickness $=0.03 \mathrm{~m}$ \\
\hline & Thermal conductivity $=0.036 \mathrm{Wm}^{-1} \mathrm{~K}^{-1}$ \\
\hline & Mass density $=30 \mathrm{~kg} \mathrm{~m}^{-3}$ \\
\hline \multirow[t]{2}{*}{ Encapsulation } & $\begin{array}{l}\text { Thickness of EVA }=0.5 \\
\text { Thermal conductivity }=0.23 \mathrm{~W} \mathrm{~m}^{-1} \mathrm{~K}^{-1}\end{array}$ \\
\hline & $\begin{array}{l}\text { Thickness of Tedlar }=0.0001 \mathrm{~m} \\
\text { Thermal conductivity }=0.36 \mathrm{~W} \mathrm{~m}^{-1} \mathrm{~K}^{-1}\end{array}$ \\
\hline
\end{tabular}
mass flow rate, specific heat capacity of working fluid, difference between the inlet and outlet temperature of water in collector, absorber area and solar radiation falling in the system at a specified time.
Table 2. Input parameters for simulation

Input parameters for the simulation of the both $\mathrm{PV} / \mathrm{T}$ water heating systems are listed in Table 2.

\section{Results and Discussion}

The simulation developed in Matlab 7.9.0 (R2009b) computer program was used to investigate the performance of both $\mathrm{PV} / \mathrm{T}$ systems. In the box type system the dimensions of the small channels were 
$1 \times 0.02 \times 0.01 \mathrm{~m}^{3}$ with total 50 numbers of channels. In sheet and tube type the total number of tubes were 5 with diameter of $0.02 \mathrm{~m}$, spacing of $0.2 \mathrm{~m}$ and length of $1 \mathrm{~m}$. All the results were carried out for the typical day of 14th of September, 2010 with the use of the meteorological conditions of Kangwon National University, Chuncheon Korea.
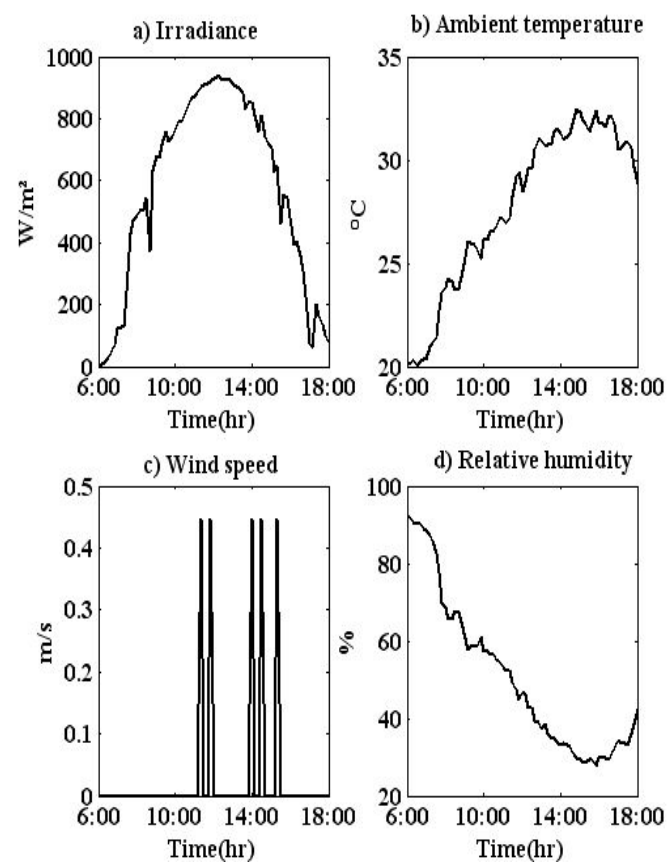

Fig. 3 Meteorological data (a) Solar irradiance (b) Ambient temperature (c) Wind speed (d) Relative humidity

The solar irradiance, ambient temperature, wind speed and relative humidity are shown in Fig. 3. The maximum solar radiation was $934 \mathrm{~W} \mathrm{~m}^{-2}$ and the maximum ambient temperature was $32^{\circ} \mathrm{C}$. The solar radiation, wind speed, relative humidity, and air temperature were recorded in the Weather Stations (Watch Dog 2000 Series Spectrum Technologies, Inc. Plainfield, IL, USA). Fig. 4 (b) showed that the collector temperature
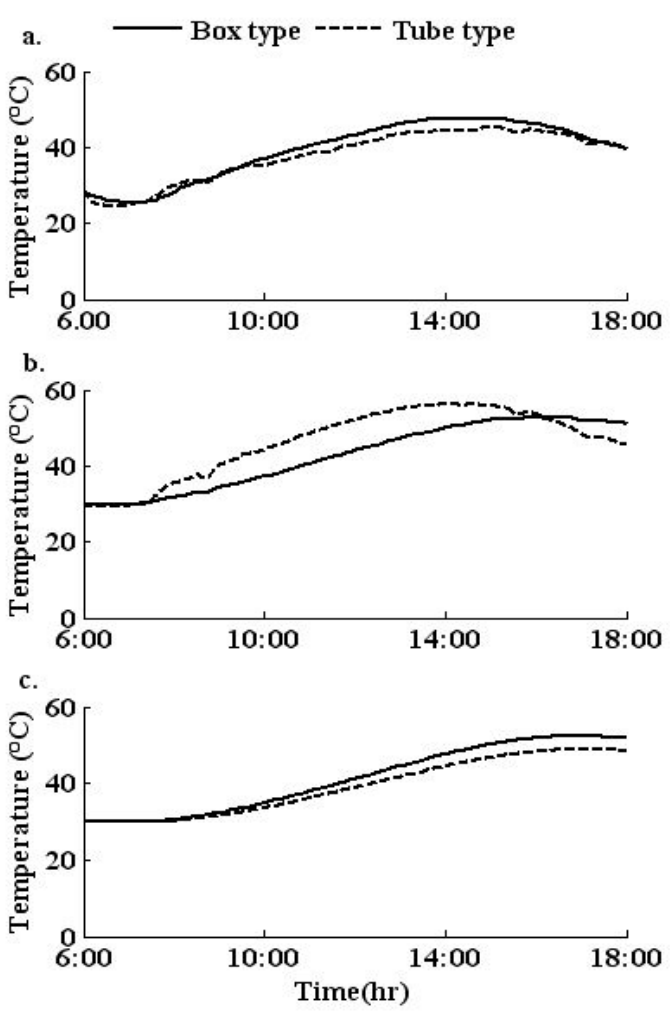

Fig. 4 Calculated temperatures of various layers in tube type and box type collectors (a) glass temperature (b) collector temperature (c) storage tank water temperature.

in tube type system was higher than the box type system. The absorber and water temperature is shown in Fig.4 (c). The temperature difference between the absorber and the water was higher in tube type $\left(7^{\circ} \mathrm{C}\right)$, but it was almost same in box type system $\left(0.06^{\circ} \mathrm{C}\right)$ (Fig.4 (c)). This showed that there was higher heat transfer from the absorber to the water in the box type and less heat transfer in the tube type system. The reason may be the higher contacting area between the water and the absorber in the box type compared to the tube type system. Due to the less contacting area with the water, tube type absorber temperature was more sensitive 
to the fluctuation in solar radiation. The effects of fluctuation of solar radiation on temperature of the tube type absorber could be observed in Fig. 4 (b). After 4 pm, with reduction of solar radiation, the temperature of tube type absorber dropped crossing the temperature of box absorber, whereas in the box type, absorber temperature could be regulated by heat energy stored in water channels (Fig. 4 (b)). The higher PV temperature of tube type system (Fig. 4 b) caused the reduction in cell efficiency (Fig. 5 c). The final temperature of water in the storage tank reached from $30^{\circ} \mathrm{C}$ to $52^{\circ} \mathrm{C}$ and $30^{\circ} \mathrm{C}$ to $48^{\circ} \mathrm{C}$ (Fig. $4 \mathrm{c}$ ) in the box type and the tube type system respectively. The maximum heat gain and cell efficiency were 376W and 14\% and 319W and 13\% in the box and tube type system respectively (Fig. $5 \mathrm{a}$ and $\mathrm{c}$ ). The higher performance in the box type system may be due to the improvement in fin efficiency and elimination of metallic bonding between the absorber plate and the tube ${ }^{12}$.

\subsection{Thermal efficiency}

The thermal efficiency of the PV/T systems were shown in Fig. 7. The efficiency was calculated under $800 \mathrm{~W} / \mathrm{m}^{2}$ solar radiation, $30^{\circ} \mathrm{C}$ atmospheric temperature and $1 \mathrm{~m} / \mathrm{s}$ air speed.

The thermal efficiency of the tube type and box type systems were found to be 0.41 and 0.51 respectively, under zero reduced temperature condition (Fig. 7). In previous studies ${ }^{3{ }^{11}}{ }^{16)}$ the thermal efficiency was found to be greater than 0.5 , but in our study for tube type the efficiency was calculated below 0.5 .
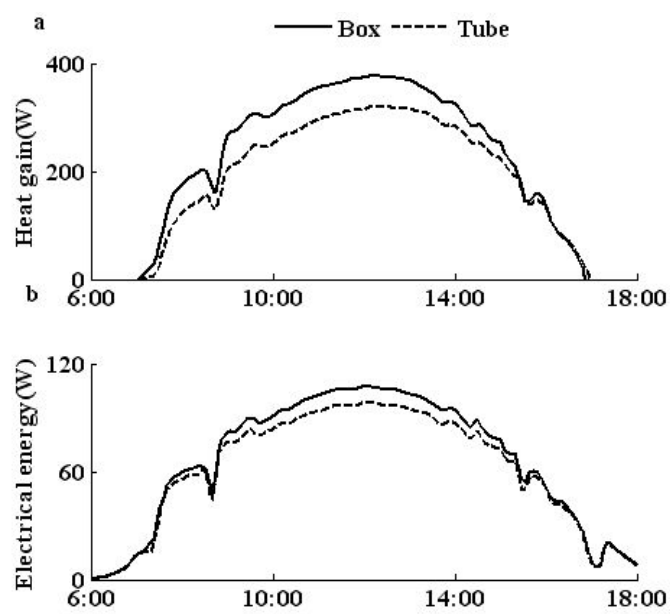

c

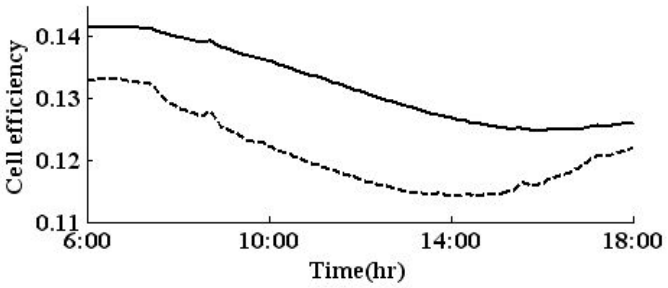

Fig. 5 Variation of (a) heat gain (b) electrical energy (c) cell efficiency in tube type and box type systems with respect to time.

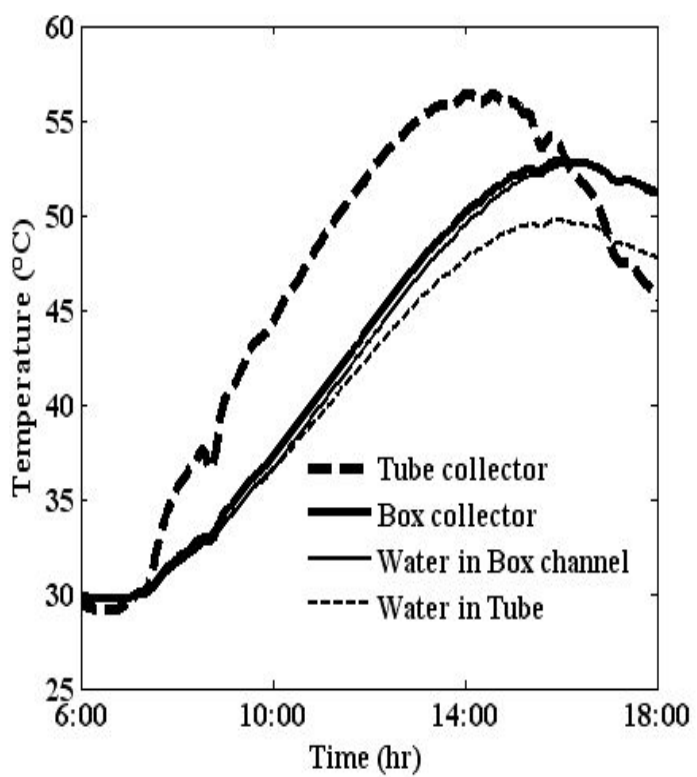

Fig. 6 Water temperature in the collector and absorber temperature of the both $\mathrm{PV} / \mathrm{T}$ systems. 


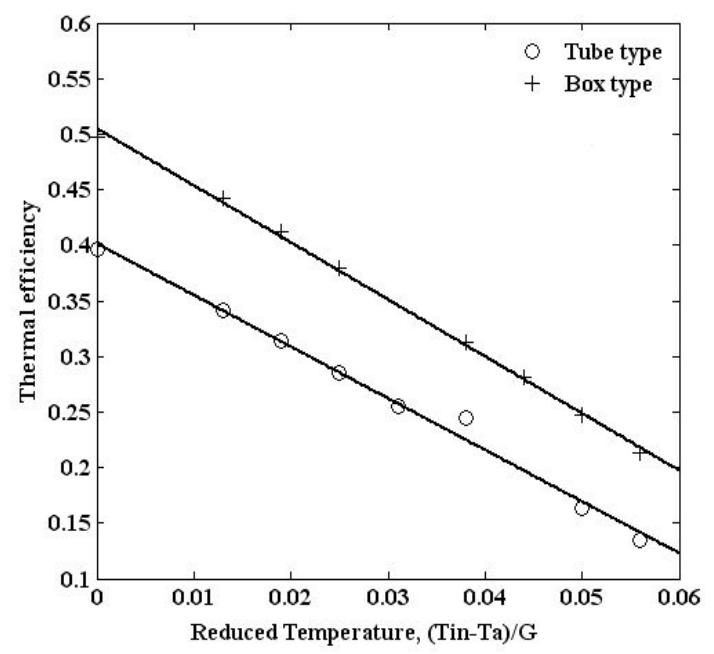

Fig. 7 Thermal efficiency of $\mathrm{PV} / \mathrm{T}$ systems

The difference between the initial and final temperature of water in the box type and tube type systems were $19^{\circ} \mathrm{C}$ and $23^{\circ} \mathrm{C}$ respectively (Fig. 6). The daily thermal efficiency of tube and box type PV/T systems were calculated as $29.5 \%$ and $35.8 \%$ respectively.

Alternatively, by considering electrical energy as a high grade form of energy gain, the energy efficiency $\eta_{f}$ is

$$
\eta_{f}=\frac{\eta_{e}}{\eta_{\text {power }}}+\eta_{t h}
$$

where, $\eta_{\text {power }}$ is the electric-power generation efficiency of the conventional power plant; its value can be taken as $38 \%{ }^{6)}{ }^{20)}{ }^{21)}$. The maximum electrical energy for the box type is 0.141 and that of the tube type is 0.133 (Fig. 5 (c)). The predicted maximum energy efficiency is 0.64 and 0.73 respectively for the tube type and the box type pvt systems. The energy efficiency of the box type system was found higher than that of the tube type system.

\section{Conclusions}

$\mathrm{PV} / \mathrm{T}$ systems with the box and tube type flow channels were studied and performance analysis were investigated. The overall performance of the box type $\mathrm{PV} / \mathrm{T}$ system was found greater than that of tube type system. The thermal efficiency at zero reduced temperature was predicted 0.41 for the tube type, and 0.51 for the box type $\mathrm{PV} / \mathrm{T}$ system. The higher performance in the box type system may be likely as a result of the improvement in fin efficiency and elimination of metallic bonding between the absorber plate and the tube. Thus, performance of the $\mathrm{PV} / \mathrm{T}$ system could be enhanced by the use of box type $\mathrm{PV} / \mathrm{T}$ collector system.

\section{References}

1. Brinkworth, B.J., Cross, B.M., Marshall, R.H., Yang,H., Thermal regulation of photovoltaic cladding, Solar Energy, Vol. 61, pp. 169-178, 1997.

2. Krauter, S., Arauja, R.G., Schroer, S., Hanitsh, R. Salhi, M.J., Triebel, C., Lemoine, R., Combined photovoltaic and solar thermal systems for façade integration and bulding insulation, Solar Energy, Vol. 67, pp. 239-248, 1999.

3. Tonui, J.K., Tripanagnostopoulos, Y., Performance improvement of $\mathrm{PV} / \mathrm{T}$ solar collectors with natural air flow operation, Solar Energy, Vol. 82. pp. 1-12, 2008.

4. McCabe J., Optimization of photovoltaic/thermal collectors, Proceedings of Solar 2004 Conference, Portland, OR, USA, ISEC2004-65180.

5. Lalovic, B., Kiss, Z., Weakliem, H., A 
hybrid amorphous silicon photovoltaic and thermal solar collector, Solar Cells, Vol 19, pp. 131-138, 1986.

6. Huang, B.J., Lin, T.H., Hung, W.C., Sun, F.S., Performance evaluation of solar photovoltaic/thermal systems, Solar Energy, Vol. 70, pp. 443-448, 2001

7. Tripanagnostopoulos, Y., Nousia, T.H., Souliotis, M., Yianoulis, P., Hybrid photovoltaic/thermal solar systems, Solar Energy Vol. 72, pp. 217-234, 2002.

8. Florschuetz, L.W., Extension of the Hottel-Whiller Model to the analysis of combined photovoltaic/thermal flat plate collectors, Solar Energy, Vol. 22, pp. 361-366, 1979.

9. Bergene, T., Lovvik, O.M., Model calculations on a flatplate solar heat collector with integrated solar cells, Solar Energy, Vol. 55, No. 6, pp. 453-462, 1995.

10. Garg, H.P., Agarwall, R.K., Some aspects of a PV/T collector:forced circulation flat plate solar water heater with solar cells, Energy Conversion and Management, Vol. 36, No. 2, pp. 87-99, 1995.

11. Zondag, H.A., The yield of different combined PV-thermal collector designs, Solar Energy, Vol. 74, pp. 253-269, 2003.

12. Chow, T.T., Performance analysis of photovoltaic-thermal collector by explicit dynamic model, Solar Energy, Vol. 75, pp. 143-152, 2003.

13. Charalambous, P.G., Maidment, G.G., Kalogirou, S.A., Yiakoumetti, K., Photovoltaic thermal (PV/T) collectors: A review, Applied Thermal Energy, Vol. 27, pp. 275-286, 2007.

14. Zondag, D.W., De Varies, W.G.J., Van Helden, R.J.C., Zonlingen, V., Vansteenhoven, A.A.,
The Thermal and Electric Yield of PV Thermal Collector, Solar Energy, Vol. 72, No. 2, pp. 113-128, 2001.

15. Chow, T.T., Ji, J., He, W., Photovoltaic-thermal collector system for domestic application, ASME Journal of Solar Energy Engineering, Vol. 129, pp. 205-209, 2007.

16. Chow, T.T., Hybrid photovoltaic-thermosyphon water heating system for residential application, Solar Energy, Vol. 80, pp. 298-306, 2006.

17. Duffie, J.A., Beckman, W.A, Solar Engineering of Thermal Processes, John Wiley and Sons Inc, New York, 1991.

18. Hollands, K.G.T., Unny, T.E., Raithby, G.D., Konicek, L., Free convective heat transfer across inclined air layers. Journal of Heat Transfer, ASME Transactions Vol. 98, pp. 189 - 193, 1976.

19. Kays, W.M., Crawford, M.E., Convective Heat and Mass Transfer, third ed. Mc Graw Hill, New York, 1993.

20. Tiwari, A.Sodha, MS., Performance evaluation of solar PV/T system: An experimental validation, Solar Energy,Vol. 80, pp.751-759, 2006.

21. He,W., Chow,T.T., Ji,J., Lu,J., Pei,G., Chan,L. ,Hybrid photovoltaic and thermal solar collector designed for natural circulation of water, Applied Energy,Vol. 83, pp.199-210, 2006.

한국태양에너지학회 논문집 Vol. 31, No. 5, 2011 